\title{
Interpretation of The Phrase "Coercion" in The Compilation of Islamic Law as Reasons for Cancellation of Marriage
}

\author{
Neng Widya Millyuner ${ }^{1}$, Adi Nur Rohman ${ }^{2}$, Elfirda Ade Putri ${ }^{3}$ \\ ${ }^{123}$ Fakultas Hukum, Universitas Bhayangkara Jakarta Raya \\ Email: nengwidya@gmail.com; adi.nur@dsn.ubharajaya.ac.id; elfirdade.putri@gmail.com
}

Article info

Received: Sep 2, $2021 \quad$ Revised: Oct 20, $2021 \quad$ Accepted: Nop 25, $2021 \quad$ Published: Dec 9, 2021

DOI: https://doi.org/10.31599/krtha.v15i2.844

Keywords : $\quad$ coercion, marriage annulment, Islamic Law Compilation

Abstract : $\quad$ Marriage is a common thing in society with ubudiyyah elements in it. However, legal issues often accompany the sanctity of the marriage bond itself, such as the cancellation of a marriage due to an element of coercion from a third party. Article 71 Compilation of Islamic Law (KHI) states that one of the reasons for being able to apply for a marriage cancellation is because of coercion when the marriage took place. The purpose of this study is to analyze the meaning of the phrase "coercion" as a reason for annulment of marriage and its accompanying legal implications. This type of research is classified as normative-empirical legal research using a statutory approach and a conceptual approach plus a sociological approach as a tool. This research refers to a variety of primary, secondary and tertiary legal materials compiled and traced through literature studies and interviews with judges of the Religious Courts. The legal materials that have been collected are then analyzed descriptively and analytically. The results showed that what is meant by coercion in marriage is a marriage that occurs not because of one's own will or feels that he is under threat. As a form of legal consequence, annulment of a marriage by force is different from divorce, where the marriage bond that occurred before the breakup of the marriage is considered never to have occurred.

Kata kunci : paksaan, pembatalan perkawinan, Kompilasi Hukum Islam

Abstrak : Perkawinan merupakan suatu hal yang lazim terjadi di masyarakat dengan unsurunsur ubudiyyah di dalamnya. Meski demikian, persoalan hukum kerap mengiringi kesucian ikatan perkawinan itu sendiri seperti halnya pembatalan perkawinan akibat adanya unsur paksaan dari pihak ketiga. Pasal 71 Kompilasi Hukum Islam (KHI) menyebutkan bahwa salah satu alasan untuk dapat mengajukan pembatalan perkawinan adalah karena adanya paksaan disaat perkawinan itu terjadi. Tujuan penelitian ini adalah menganalisis pemaknaan frasa "paksaan" sebagai alasan pembatalan perkawinan serta implikasi hukum yang menyertainya. Jenis penelitian ini tergolong penelitian hukum normatif-empiris dengan menggunakan pendekatan perundang-undangan dan pendekatan konseptual ditambah pendekatan sosiologis sebagai alat bantu. Penelitian ini merujuk kepada berbagai bahan hukum primer, sekunder dan tersier yang dihimpun dan ditelusuri melalui studi kepustakaan dan wawancara kepada hakim Pengadilan Agama. Bahan hukum yang berhasil dihimpun selanjut dianalisis secara deskriptif analitis. Hasil penelitian memperlihatkan bahwa yang dimaksud dengan paksaan dalam 
perkawinan adalah perkawinan yang terjadi bukan karena kehendak diri sendiri atau merasa dirinya dibawah ancaman. Sebagai bentuk konsekuensi hukumnya, pembatalan perkawinan karena paksaan berbeda dengan perceraian dimana ikatan perkawinan yang terjadi sebelum putusnya perkawinan dianggap tidak pernah terjadi.

\section{INTRODUCTION}

Marriage according to Law Number 1 of 1974 concerning Marriage is an outer and inner bond between a man and a woman as husband and wife with the aim of forming a happy and eternal family based on the One Godhead. ${ }^{1}$ In another sense, it is stated that marriage is a contract that justifies association and limits rights and obligations as well as mutual assistance between a man and a woman who are both not mahram. ${ }^{2}$

The Compilation of Islamic Law (KHI) also provides a definition of marriage with several additional explanations, as follows: "Marriage according to Islam is a marriage that is a strong contract (miitsaqan ghalizhan) to obey Allah's commands and carry it out is worship". The expression of a very strong contract or mithaqan ghaliza is an explanation of the expression "inner and outer bond" contained in the formulation of the Act which means that the marriage contract is not only a civil agreement. The phrase "to obey Allah's commands and carry them out is worship" is an explanation of the phrase "based on the One Godhead" in the Law. ${ }^{3}$ This further explains that marriage for Muslims is a religious event and carrying it out has carried out acts of worship. ${ }^{4}$

Marriage law in placing the pillars and conditions there are differences of opinion among scholars. However, all scholars agree that what must be in a marriage includes a marriage contract, the prospective groom, the prospective bride, the guardian of the prospective bride, witnesses who witness the marriage contract, and a dowry or dowry. ${ }^{5}$ The Marriage Law does not discuss the pillars of marriage. The Marriage Law only discusses the conditions of marriage relating to the elements or pillars of marriage. KHI clearly discusses the pillars of marriage as contained in Article 14, all of which follow the Syafi'i fiqh by not including the dowry in the pillars. ${ }^{6}$

${ }^{1}$ Republik Indonesia, Undang-Undang Nomor 1 Tahun 1974 tentang Perkawinan, pasal 1.

2 Martiman Prodjohamidjojo, Hukum Perkawinan Indonesia, (Jakarta: Indonesia Legal Center Publishing, 2011), hlm. 8.

${ }^{3}$ Ibid, hlm, 5.

${ }^{4}$ Ibid

${ }^{5}$ Pura, M. H. ., \& Faridah, H. (2020). Aspek Sosiologis Tindak Pidana Perzinaan Atas Suami Yang Nikah Dibawah Tangan (Siri) Tanpa Izin Poligami. KRTHA BHAYANGKARA, 14(2). https://doi.org/10.31599/krtha.v14i2.141

${ }^{6}$ Ibid, hlm 9 
In this modern era, we often hear the word matchmaking which means marriage under pressure and coercion to be united in a sacred marriage for a man and a woman. It can be said that forced marriages or marriages due to coercion are marriages carried out without the consent of the two prospective brides. The element of coercion in marriage regulations in Indonesia is included in one of the reasons for submitting marriage annulment as a way to break the marriage bond.

A complete and detailed discussion of the annulment of marriage has been explained in Article 22 of the Marriage Law that "A marriage can be annulled, if the parties do not meet the requirements to hold the marriage." Meanwhile, in the KHI, articles 70 to 76 are regulated regarding the reasons that can be submitted for the annulment of a marriage. However, even though there are reasons for annulment of marriage, not everyone can apply for annulment of marriage. Meanwhile, the annulment of marriage can be proposed by one of the husband and wife concerned, among others because the family members are blood relatives in a straight line upward from the husband or wife. In addition, it can also be submitted by an authorized official or appointed official or other person who has a direct legal interest in the marriage. It is clear about the parties who can apply for annulment of marriage in the Marriage Law, which is regulated in Article 23 and Article 24. While in the Compilation of Islamic Law, it is regulated in Article $73 .^{8}$

In Islamic law, marriage based on coercion is not allowed in any form, including in the case of marriage. Because the relationship between two people based on compulsion will result in psychologically unfavorable for both husband and wife. In principle, a marriage can be sued for its annulment by certain people. The cancellation carried out by a certain person must be based on certain conditions in accordance with the laws and regulations. In the matter of marriage, forced marriage is very influential in realizing a harmonious household because the impact that will arise will be detrimental to both parties. So, the marriage needs to be freed from all forms of outside interference, because if there is such a thing it will lead to an annulment of the marriage in the marriage.

This study aims to look at the concept of the phrase "coercion" in the marriage law regulations in Indonesia. The interpretation of the meaning of "coercion", especially by

\footnotetext{
${ }^{7}$ Adi Nur Rohman, (2020). Upaya Memantapkan Peraturan Isbat Nikah Dalam Hukum Perkawinan Di Indonesia. Jurnal Hukum Sasana, 6(1). https://doi.org/10.31599/sasana.v6i1.173

${ }^{8}$ http://journal.iainlangsa.ac.id/index.php/qadha/article/download/173/109, hlm 9. diakses pada pukul 20.20

${ }^{9}$ Gatot Efrianto. (2020). Akibat Hukum Dari Perkawinan Adat Baduy Dalam Perspektif UndangUndang Nomor 1 Tahun 1974. Jurnal Hukum Sasana, 5(2). https://doi.org/10.31599/sasana.v5i2.100
} 
judges of the Religious Courts, is important considering that the element of coercion is the reason for submitting an annulment of marriage which has a more serious legal impact than divorce. In addition, this study will also analyze the legal impact arising from the occurrence of marriage annulment in the Religious Courts.

\section{DISCUSSION}

\section{Basic Concepts of Marriage in Indonesia: A Juridical Review}

Marriage comes from the word "marry", which etymologically means forming a family with the opposite sex (having sex or having sex). Marriage is also called marriage which comes from the word "nikah" which means al-jam'u and al-dhammu which means to gather / collect, include each other and is used to mean intercourse (wath'i). The word "marriage" is often used (wath'u al-zaujah) for intercourse (coitus). In addition, (zawaj) for the meaning of aqdu al-tazwij or marriage contract. In terms of terminology, marriage is a contract determined by syara' to allow fun between men and women and justify the fun of women with men. ${ }^{10}$

Marriage is a form of inner and outer bond between a man and a woman as husband and wife, while the purpose of marriage is to form a happy and eternal family based on the One Godhead. The sentence "bond physically and mentally" implies that marriage is not enough just to have "bond birth" or ties of heart alone, but must be both. ${ }^{11}$ In another sense, marriage is defined as a contract that justifies association and limits the rights and obligations as well as mutual assistance between a man and a woman, both of whom are not married. ${ }^{12}$

In Indonesian, marriage comes from the word "kawin", which etymologically means forming a family with the opposite sex (having sex or having sex). Marriage is also called marriage which comes from the word "nikah" which means al-jam'u and al-dhamu, which means to gather / collect, include each other and is used for intercourse (wat'i). the word "marriage" is often used (wat'u al-zaujah) for intercourse (coitus). In addition, (zawaj) for the meaning of aqdu al-tazwij or marriage contract. In terminology, marriage

${ }^{10}$ Mahmudin Bunyamin dan Agus Hermanto, Hukum Perkawinan Islam, (Bandung: CV. Pustaka Setia, 2017), hlm. 1.

${ }^{11}$ K.Wantjik Saleh. S.H,Hukum Perkawinan Indonesia, (Jakarta:Ghalia Indonesia, 1980), hlm 14

${ }_{12}$ MR Martiman Prodjohamidjojo, MM.MA, Hukum Perkawinan Indonesia, Jakarta: Indonesia Legal Center Publishing,2011), hlm. 8. 
is a contract stipulated by the syara to allow fun between men and women and justify the fun of women with men. ${ }^{13}$

Marriage according to Islam is marriage, which is a strong contract or miitsaqan ghalizhan to obey Allah's commands and carry out it is worship. The expression of a very strong contract or mithaqan ghaliza is an explanation of the expression "inner and outer bond" contained in the formulation of the Act which means that the marriage contract is not only a civil agreement. ${ }^{14}$ The phrase "to obey Allah's commands and carry them out is worship" is an explanation of the phrase "based on the one and only God" in the Law. ${ }^{15}$

The purpose of marriage, as described by Khoiruddin Nasution, includes 5 things, namely (a) to obtain happiness and peace while at the same time building a sakinah family, (b) regenerating mankind (reproduction) on earth or obtaining pious offspring, (c) fulfilling biological needs, (d) to maintain honor, and (e) to worship/follow the sunnah of the Prophet.

The principles or principles of marriage according to Law Number 1 of 1974 are the formation of a happy and eternal family. Legal marriage according to each religion, marriage registration, the principle of open monogamy, the principle that the prospective husband and wife are mature in spirit, the age limit for marriage, divorce is complicated, the position of husband and wife is balanced. Thus marriage and the purpose of marriage are closely related to religion, so religious education in the family is a sine quo non condition to form a happy family. Because in fact religion will make life and human life more meaningful.

In the implementation of marriage, the prospective bride and groom must meet the pillars and conditions of marriage. The pillars of marriage are the essence of marriage itself, so without one of the pillars, marriage is impossible to carry out, while what is meant by marriage conditions is something that must exist in marriage but does not include the essence of marriage. If any of the conditions for marriage are not met, then the marriage is invalid.

The statement as mentioned above is also explained again in the explanation section of Article 2 of the Marriage Law. From this explanation, it can be concluded that whether

${ }^{13}$ H. Mahmudin Bunyamin, Lc., M.A. Agus Hermanto, M.H.I., Hukum Perkawinan Islam, (Bandung: Cv Pustaka Setia, 2017), hlm. 1.

14 Adi Nur Rohman. (2019). The Existence Of Maslahah Mursalah As The Basis Of Islamic Law Development In Indonesia. Krtha Bhayangkara, 13(2). https://doi.org/10.31599/krtha.v13i2.9

15 Ibid, hlm, 5. 
a marriage is legal or not depends on the religious provisions and beliefs of each individual or person who will carry out the marriage. The terms of marriage are very important, because a marriage that does not meet the requirements specified in the law, then the marriage can be threatened with annulment or can be canceled. ${ }^{16}$

According to Western Civil Law (KUHper), the conditions for a valid marriage (material requirements) include:

a. The principle of monogamy applies (article 27 of the KUH per)

b. There must be an agreement and free will between the man and the woman (article 28 of the KUH per)

c. A man is 18 years old and a woman is 15 years old (Article 29 of the Civil Code per)

d. There is a waiting period for a divorced woman, which is 15 years (Article 29 of the Criminal Code)

e. Minor children must obtain a marriage permit from their parents (Article 35 of the Civil Code).

f. Not subject to a marriage ban (Articles 30-33 KUHper) ${ }^{17}$

The marriage law contains a broad content. Not only contains "Marriage" and "Divorce", it also regulates the position of the child, rights and obligations between parents and children, guardianship, proof of the origin of the child. In addition, it also regulates matters that are not known in Customary Law and Islamic Law, such as only about "Marriage Agreements". Besides, it not only regulates the relationship and acts of marriage (material law) but also contains provisions relating to the judiciary (formal law). ${ }^{18}$

The Compilation of Islamic Law (KHI) article 2 states "Marriage according to Islamic law is marriage, which is a very strong contract or mitssaqan ghalidzan to obey Allah's commands and carry it out is worship" as explained in the article that marriage is worship in life in order to create a marriage that is harmonious. sakinah, mawaddah and warrahmah. In article 4 which contains "marriage is legal, if it is carried out according to Islamic law in accordance with article 2 paragraph (1) of Law No.1 of 1974 concerning Marriage" that marriage is legal if the conditions and pillars have been fulfilled. ${ }^{19}$

${ }^{16}$ Yusnindar Rachman .H, "Pembatalan Perkawinan Serta Akibat Hukumnya", Tesis, Semarang:2006, hlm 22-23.

17 P.N.H. Simajuntak. S.H, Hukum Perdata Indonesia, (Jakarta:KENCANA, 2015), hlm 36.

18 K.Wantjik Saleh. S.H,Hukum Perkawinan Indonesia, (Jakarta:Ghalia Indonesia, 1980), hlm 6.

${ }^{19}$ Kompilasi Hukum Islam 


\section{Cancellation of Marriage: Legal Normative Study}

In Law Number 1 of 1974 concerning Marriage, Article 22 is expressly stated that a marriage can be annulled, if the parties do not meet the requirements to enter into a marriage. In Article 25 which contains "applications for annulment of marriage are submitted to the Court in the jurisdiction where the marriage is taking place or the place of residence of both husband and wife, husband or wife" which means that the annulment of marriage can be processed in the Court where the marriage took place or where the wife or husband lives.

Article 27 of the marriage law states that:

1. A husband or wife may apply for an annulment of marriage if the marriage is held under threat of violation of the judge.

2. A husband or wife can apply for an annulment of marriage if at the time of the marriage there is a misunderstanding about the husband or wife.

3. If the threat has ceased, or the guilty suspect is aware of the situation, and within 6 (six) months after that, he is still living as husband and wife, and does not use it only to apply for annulment, then his right is void.

If the marriage is carried out not meeting the requirements in accordance with Law No. 1 of 1974, then the marriage can be canceled because the marriage is a legal act, of course, if the marriage is canceled it will have legal consequences. ${ }^{20}$ In preventing the cancellation of marriages, the things that can be done by government agencies such as the KUA are as follows:

1. Checking the completeness of the registration administration and checking the status/correctness of the data on the registration file at the time of registration carefully and in accordance with the regulations.

2. Installing the announcement of the marriage will, before the marriage will is published through the announcement, the KUA must state that the marriage can be continued. If there are other parties who find anomalies or mistakes between the two prospective brides after knowing the announcement, they can directly contact the KUA.

${ }^{20}$ Alinapia, "Akibat Hukum Pembatalan Perkawinan Karena Status Wali Nikah Yang Tidak Sab Menurut Undang-Undang Nomor 1 Tabun 1974”, Jurnal Justitia, Vol 1, No 4, Desember 2014 , hlm 379. 
3. Re-checking the correctness of the statement of the prospective bride or guardian at the time of registration before the marriage contract process is carried out.

4. Announce to the witness that the bride and groom can be married off immediately and previously notify the witness of his/her functions and duties in the process of the marriage contract taking place.

5. Inform all attendees about the terms and pillars of marriage

6. Inform all attendees about the conditions and pillars of marriage, so that they can also identify whether it is true that the two prospective brides are a legal couple or there are things that hinder the marriage or not.

7. Doing marriage refusal if found barriers to marriage.

8. Asking whether or not the prospective bride and groom to marry. ${ }^{21}$

If there is an annulment of the marriage, either in the form of a violation of the marriage law, or there are obstacles that do not allow the marriage to continue, then there will be legal consequences in the form of not allowing the husband to refer to his ex-wife as long as the wife is serving the iddah period, but if both wish to continue their marriage. they have to continue their marriage, they have to do a new marriage contract. Another consequence is that the annulment of the marriage does not reduce the number of thalass. ${ }^{22}$

The annulment of a marriage has several consequences, namely: ${ }^{23}$

a. The annulment of a marriage means that there is a court decision stating that the marriage carried out is invalid. The legal consequence of the annulment is that the marriage becomes a decision for the parties whose marriage is canceled to return to the status of beginners because the marriage is considered non-existent.

b. The cancellation of the marriage begins after the decision of the religious court has permanent legal force, but applies retroactively from the time the marriage takes place.

c. The decision to cancel a marriage does not apply retroactively to children born to third parties who have rights and obligations.

${ }^{21}$ Faisal, "Pembatalan Perkawinan dan Pencegahannya", Jurnal Hukum Islam dan Perundang-undangan, Vol 4 No 1 Tahun 2017, hlm 10-15 hlm 31-33.

${ }^{22}$ Yusnindar Rachman .H, "Pembatalan Perkawinan Serta Akibat Hukumnya", Tesis, Semarang:2006,

23 Dr.H.Kumedi Ja'far S,Ag.,M.H, Hukum Keluarga Islam Di Indonesia, (Sukabumi:Arjasa Pratama,2020), hlm 112. 
According to Muhyar, a judge at the Bekasi Religious Court, an annulment of a marriage is a marriage that is considered invalid and never existed. ${ }^{24}$ Marriage annulment means to consider a marriage that has been done as an event that is not valid or never existed. Legal protection is always related to the existence of rights and obligations. As a result of the annulment of marriage as stated in Article 28 paragraph (2) of Law No. 1 of 1974 that "the decision to cancel a marriage does not apply retroactively to children born from that marriage". this is confirmed in article 75 and article 76 in the Compilation of Islamic Law. Children remain "legitimate" children so that the annulment of marriage will not break the legal relationship between the child and his parents. Both parents are obliged to maintain and educate their children as well as possible even though their marriage has been annulled by the Court. This happens because marriage is a matter that must be subject to statutory provisions.

The marital relationship will provide legal protection guarantees to parties related to marriage, both husband, wife, children and third parties. Marriage as a legal act has legal consequences and the legal consequences are desired by those who act. In view of the provisions in Article 42 of Law No. 1 of 1974 that "a legitimate child is a child born in or as a result of a legal marriage". The legal consequences in marriage are closely related to the legitimacy of children and the rights and obligations of the parties, namely husband and wife, so the terms and pillars of marriage according to Law No. 1 of 1974 and the Compilation of Islamic Law must be fulfilled by the parties who will carry out the marriage.

Therefore, the annulment of marriage does not have a negative effect on the child's status. The child remains as a legitimate child and will not break the legal relationship between the child and his parents. A marriage that has been annulled will still have legal consequences for both husband and wife and for their children, if the marriage is carried out in good faith. So even though the marriage relationship between husband and wife has been decided and annulled by the court, the court's decision does not affect the position of the children born in the marriage and they are still considered legitimate children born from a legal marriage.

The legal consequences of the annulment of the marriage do not necessarily eliminate the obligation to parents in abandoning their children. Both the Marriage Law

${ }^{24}$ Hasil Wawancara Dengan Bapak Muhyar Hakim Pengadilan Agama Bekasi, Pada Tanggal 12 Juni 
and the Compilation of Islamic Law expressly state that children born in annulled marriages are declared not retroactive, even though one of the parents has bad intentions/both have bad intentions. This is based on a sense of humanity and the interests of children so it deserves legal protection.

The annulment of a marriage must receive attention from the parties concerned, because it can have an impact on the children and wife. Children are certainly many victims due to the marriage of their parents due to the case of marriage annulment, so these parties need to pay attention to the fate of the child, so that the child does not become a victim. Meanwhile, prior to the annulment of the marriage, it is still considered a valid marriage. It's just that after it is decided that the marriage is annulled, the wife cannot get the iddah maintenance right as is the case with divorce.

\section{Coercion as a Reason for Cancellation of Marriage}

In the Compilation of Islamic Law in Article 71 Letter $\mathrm{f}$ a marriage can be annulled if "a marriage is carried out by force" so, a marriage can be annulled if the woman or the man has an element of coercion to marry. ${ }^{25}$ In elemental marriages because of "coercion" can have a big influence on the married life of husband and wife. The existence of coercion can occur by the husband or wife, because of a threat or not from one's own will to carry out a marriage.

In Arabic, forcing or forcing is often referred to as ijbar or ikrah. But linguistically he has no specific meaning if the word stands alone. Forced marriage is very influential in a marriage bond, because marriage must be on a voluntary basis, should not be forced or the bride and groom feel under threat. The existence of the term forced marriage is because marriage cannot take place unless the pillars are fulfilled. And one of the pillars of marriage is the guardian of the girl. He who has the full right to perform the consent, the guardian marries not for himself but for his child.

The effect of forced marriage on household harmony can have a negative impact on both or one of the husband or wife parties, the negative impacts are:

a. Can't create a sakinah mawaddah angry family

b. Unable to fulfill the rights and obligations of husband and wife properly

${ }^{25}$ Kompilasi Hukum Islam 
c. Unable to carry out the commands of Allah SWT and the Messenger of Allah in accordance with Islamic law. ${ }^{26}$

Muhyar, one of the judges of the Bekasi Religious Court, argued that according to him, forced marriages or what is known as matchmaking are usually carried out between the parents of both parents, male or female, as guardians in marriage to create a sense of parental responsibility for the mandate given by Allah to take care of, educate, make their daughters Muslim and approve and marry off their daughters according to the readiness and maturity of a girl to avoid disobedience and sinful acts. Forced marriage is one of the ways that society goes through in marriage. There is no provision in the Shari'ah that requires or otherwise prohibits forced marriage. In today's modern era, young people are usually forced by their parents to get married immediately. Parents of course really want the best for their children, parents don't want to see their children live difficult lives, one of which is in mate problems, therefore parents feel that their choice is the right one for their children.

Forced marriage is only one way to get married, parents can marry off their children. But it is better to ask for permission and prior approval from the child so that the marriage that is carried out later will be based on the pleasure of each party, not out of compulsion. A marriage that is built on the basis of compulsion, if it continues, will disrupt the harmony of the household for the bride and groom. Because harmony begins with a sense of love, while love cannot be forced. If there is no match between the bride and groom, then whoever the person is will never be able to unite.

That parents who forcefully marry their daughters are caused by very low parental education, a mediocre economy, and community habits that are difficult to eliminate in people's lives. To parents who marry their daughters by force, they want to see their children's lives more than that and not like what their parents experienced and get whatever their children want. Besides that, he hopes that his child's life will be more than adequate, so that his son's husband will be able to help the economy in his family, especially if his child's household is more feasible than before. ${ }^{27}$

\footnotetext{
${ }^{26}$ Henni Zein, "Pembatalan Perkawinan Karena Kawin Paksa”, Tesis, 2013, hlm 7-8

${ }^{27}$ Hasil Wawancara Dengan Bapak Muhyar Hakim Pengadilan Agama Bekasi, Pada Tanggal 12 Juni
} 
There are several factors in the occurrence of forced marriages caused by very low parental education, minimal economics and socio-culture that are difficult to eliminate in the order of people's lives. for more details described as follows: ${ }^{28}$

\section{Economic Factor}

The condition of the community, especially those who live in remote areas, prefer to apply the forced marriage system to their daughters due to low-middle economic factors. This is relatively low compared to the condition of urban communities, but not a few are able to afford it. The parents who marry off their daughters forcibly want to see their children's lives more than that and not as she experienced and can get whatever the children want.

\section{Heredity Factor}

The heredity factor here is the guardians looking for prospective husbands for their daughters seen from their offspring, at least in this heredity factor a guardian is looking for prospective husbands for her daughters looking for men who come from descendants who are equal to the family of their daughters, because with equal offspring will add harmony husband and wife, if the prospective husband is sought by parents or guardians who are not equal, but at least the man is of good descent, so that his daughter will be treated well so that his family life can be carried out according to the goal, namely a peaceful and peaceful atmosphere.

3. Factors Lack of Understanding Marriage Law

People whose education level is still low make them less understanding of marriage law. This greatly affects the level of understanding of a knowledge, especially knowledge of national marriage law. They do not understand the content and intent contained in the national marriage law, which is related to Law No. 1 of 1974 CHAPTER II Article (6) and Islamic marriage law, especially regarding forced marriages.

4. Habits and Customs Factors

The habits of an area greatly affect the way of life of a group of people, these customs play a very important role in regulating the life of a community, and the community always follows the customs that apply in their respective regions. Marriage culture and its rules that apply to a society or a nation cannot be

${ }_{28}$ Dr.H.Achmad Muhlis,M.A, Mukhlis,M.H , HUKUM KAWIN PAKSA DIBAWAH UMUR (Tinjauan Hukum Positif Dan Islam), (Surabaya:CV.Jakad,2019), Hlm 18-19 
separated from the influence of culture and the environment in which the community is located and the association of the community. It is influenced by the knowledge, experience, beliefs and religions held by the community concerned. The community's habit is still strong by carrying out marriages based on coercion or known matchmaking for their children, whether matchmaking is carried out from those who are young or have reached adulthood in determining the prospective husband is the full right of the parents (guardians). ${ }^{29}$

Due to the habit of people who do not understand and deepen the meaning and content of Law No. 1 of 1974 Article 6 paragraph (1), it is usually easy for people to marry off their daughters with men of their parents' choice. There are still many who carry out marriages by means of parents marrying off their daughters by force without asking for the approval of both parties, both the prospective groom and the prospective bride.

Parties who feel that their marriage was forced or under threat, they also have the right to file an annulment of their marriage to the local Religious Court, if their marriage does not meet the requirements set out in the Marriage Law. This is in accordance with the Compilation of Islamic Law Article 71 Letter $\mathrm{f}$.

From the results of interviews, researchers describe, the issue of forced marriage is basically the same as a humanitarian issue. This is clearly seen when forced marriage for women has negative consequences for the sustainability of activities in a family. In addition, forced marriage will have an even worse impact if the husband or wife who is arranged for an arranged marriage is still underage. As a result of the matchmaking, the bride who is still immature does not really know about the characteristics of her future husband or vice versa. Women's lack of understanding in many aspects will cause anxiety, stress, fear, and anger, or even run away from their husbands.

The results of the interview with the Bekasi Religious Court Judge explained, Cases that often occur in the community in the form of coercion in marriage are:

a. The existence of forced marriages against minors because some parents have opinions such as fear that their children will have difficulty getting the right mate, fear that their children will become spinsters, fear that their children will fall into acts that violate religious and social norms such as falling into adultery.

${ }^{29}$ Ibid, hlm 20. 
b. Forced marriage because parents have no money to support and send their children to school, and feel that parents feel they have found a suitable and good mate for their children in the future.

c. Forced marriages against women and men who do not know each other because of coercion by their parents. ${ }^{30}$

In this case the researcher describes things like that can be categorized as violations of human rights in marriage. The act of coercion is one type of action that will result in another person undergoing an activity that is not in accordance with his will, is against his will or is simply forced or is under threat of being forced to follow a wish that is not his own will.

Based on the interview with the Bekasi Religious Court Judge, the researcher explained that forced marriages cannot be separated from the role of marriage guardians, because usually it is the marriage guardian who has the right to marry off their children or people under their guardianship. Guardians in marriage are pillars that must be fulfilled for prospective brides who are ready to marry, if these pillars are not fulfilled then their marital status is invalid. It can be understood that the right to determine a life partner or mate is entirely in the hands of the party who will carry out the marriage itself, not determined by other people, including the guardian.

If forced marriages do occur, then usually women, in this case the wife, are the first and main victims. In societies where fatherhood is more respected, such as in Java, women are often the ones who are always blamed. Judging from people's habits, it can be interpreted that forced marriages can immediately cause anxiety because the perpetrator feels that he does not have the ability, authority, and choice of any decisions. Forced marriages that are usually experienced by many women are basically psychologically unjustified, because there will be many negative consequences, both concerning the physical and psychological health of women. Psychic consequences will appear for the first time when the matchmaking is carried out because when a woman is paired with a man she does not want, immediately a turmoil and conflict will arise in her heart.

Although it is not explained in detail by positive law regarding forced marriage, the researcher describes the meaning of the principle of voluntary or free consent and without coercion from the two prospective brides and grooms, which is also mentioned by Law

${ }^{30}$ Hasil Wawancara Dengan Bapak Muhyar Hakim Pengadilan Agama Bekasi, Pada Tanggal 12 Juni 
No. 1 of 1974 concerning Marriage, It can be explained that what is meant by forced marriage is a marriage that occurs because of an element of coercion from another person, which in this case is his parents or someone else. Which is where parents force their children to marry the person of their choice without the consent or willingness of the child. Forced marriages can be interpreted as marriages not of their own volition or marriages that occur because of pressure or pressure obtained by the bride or groom. Forced marriage itself is a form of parental or family attitude that does not respect human rights, because marriage issues are the same as human life choices in shaping and building survival in a family. The act of coercion in marriage carried out by parents or guardians is essentially an act of tyranny that may be unintentional by parents against their children.

The consent of the prospective groom and bride itself is one of the important things to carry out a marriage in accordance with what has been regulated in Law Number 1 of 1974 concerning Marriage as well as in the Compilation of Islamic Law. The parents of the prospective bride and groom should not refuse marriage if the two prospective brides already know well. And if the marriage is not based on the consent of the two prospective brides, then the parents of the prospective bride and groom should not force their will to marry off their children.

The researcher concludes that the meaning of coercion and threat have the same meaning, namely, both coercion and threat are acts or intentions of the coercion to require the other party to do something desired by the coercion. Both coercion and threats will put pressure on the coerced party, so that because of their inability to resist the coercion, the prospective bride and groom who are forced to do so will do it, because if they refuse, they are afraid that something will happen. The impact can occur in the future, where the forced party feels aggrieved, and will file for annulment of the marriage due to coercion.

In the ark of marriage, marriage is forced or under threat, contrary to the meaning and meaning of marriage as aspired or described by Law Number 1 of 1974, that marriage is an inner and outer bond between a man and a woman as husband and wife. with the aim of forming a happy and eternal family or household based on God Almighty in article 1.

The results of the interview with the Bekasi Religious Court Judge, Mr. Muhyar, argued that efforts to prevent forced marriages, the right to determine a prospective wife or husband is absolutely in the hands of each candidate, this should not be regulated by anyone, not even the father or mother. And if a father or mother does not approve of the 
candidate that is chosen by their child, then the disapproval of the father or mother is not at all categorized as an act of the child disobeying his parents, in this case the child can hold the right to choose not a parent. This needs to be considered by parents so that they do not misunderstand in applying religious provisions regarding filial children to parents. If there is a disagreement between the child's views and the parents in choosing the partner they want, then what is entitled to be carried out is the child's desire, not the parents' wish. ${ }^{31}$

Coercion at the time of marriage can indeed be used as a reason for annulment of marriage as has been regulated in Article 71 of the Compilation of Islamic Law, which states that a marriage can be annulled if:

a. A person commits polygamy without the permission of the Religious Court.

b. The woman who was married was later discovered to be the wife of another man who was mafqud;

c. The woman who is married is still in the iddah of another husband;

d. Marriage that violates the marriage age limit as stipulated in Article 7 of Law No. 1 of 1974;

e. The marriage is carried out without a guardian or carried out by an illegitimate guardian;

f. Forced marriages.

However, it must also be noted that in article 72 paragraph (3) of the Compilation of Islamic Law and article 27 paragraph 3, that it is given a time limit for submitting a request for annulment of marriage due to coercion or threats to marry, which reads: has stopped, or the guilty suspect is aware of the situation, and within a period of 6 (six) months after that he is still living as husband and wife, and does not exercise his right to apply for annulment, then his right is void."

Marriage is a noble thing, because marriage is the most useful way in maintaining self-respect and avoiding things that are prohibited by religion. The purpose of marriage is to lower the views of the opposite sex and fortify oneself from vile and dirty acts that can demean dignity.

\section{CONCLUSION}

${ }^{31}$ Hasil Wawancara Dengan Bapak Muhyar Hakim Pengadilan Agama Bekasi, Pada Tanggal 12 Juni 
Forced marriage is a marriage that is forced by one of the parties to the prospective groom or bride. Forced marriages are marriages that occur not because of their own will or feel themselves under threat. Forced marriages usually occur by parents to their children by forcing them to marry according to their parents' choices, which according to their parents are good. Usually these parents find a mate for their children and force their children to marry the parents' choice.

In the mechanism of Marriage Cancellation at the Bekasi Religious Court, the Court has followed the rules contained in the applicable law. The procedure in handling a case, the Bekasi Religious Court will decide the case according to the facts and evidence provided by the applicant, the judge will give a fair decision to the applicant and the respondent. Forced marriages usually occur by parents to their children by forcing them to marry according to their parents' choices, which according to their parents are good. In the mechanism of Marriage Cancellation at the Bekasi Religious Court, the Court has followed the rules contained in the applicable law. The procedure in handling a case, the Bekasi Religious Court will decide the case according to the facts and evidence provided by the applicant, the judge will give a fair decision to the applicant and the respondent.

\section{SUGGESTION}

The need to review and understand the terms and pillars of marriage Law No. 1 of 1974 concerning Marriage among today's society, especially parents. So that forced marriages do not occur by parents to their children.

\section{BIBLIOGRAPHY}

Republic of Indonesia, Law Number 1 of 1974 concerning Marriage, article 1.

Prodjohamidjojo, Martiman. Hukum Perkawinan Indonesia, Jakarta: Indonesia Legal Center Publishing, 2011.

http://journal.iainlangsa.ac.id/index.php/qadha/article/download/173/109 , hlm 9. diakses pada pukul 20.20

Bunyamin, Mahmudin dan Agus Hermanto, Hukum Perkawinan Islam, (Bandung: CV. Pustaka Setia, 2017.

Efrianto. Gatot. (2020). Akibat Hukum Dari Perkawinan Adat Baduy Dalam Perspektif Undang-Undang Nomor 1 Tahun 1974. Jurnal Hukum Sasana, 5(2). https://doi.org/10.31599/sasana.v5i2.100 
Saleh, K.Wantjik, Hukum Perkawinan Indonesia, Jakarta:Ghalia Indonesia, 1980.

Prodjohamidjojo, MR Martiman. Hukum Perkawinan Indonesia, Jakarta: Indonesia Legal Center Publishing,2011.

Mujibussalim, Mohd.Din. Eli Dani Isma, "Kebijakan Kriminal Dalam Penganggulangan Perkawinan Di Bawah Umur”, Jurnal Hukum Islam, Vol 7, No 1, Januari-Juni 2017

Bunyamin, H. Mahmudin. Agus Hermanto, Hukum Perkawinan Islam, Bandung: Cv Pustaka Setia, 2017.

Rachman, Yusnindar. "Pembatalan Perkawinan Serta Akibat Hukumnya", Tesis, Semarang: 2006.

Rohman. Adi Nur, (2019). The Existence of Maslahah Mursalah as The Basis of Islamic Law Development in Indonesia. Krtha Bhayangkara, 13(2). https://doi.org/10.31599/krtha.v13i2.9

(2020). Upaya Memantapkan Peraturan Isbat Nikah Dalam Hukum Perkawinan Di Indonesia. Jurnal Hukum Sasana, 6(1). https://doi.org/10.31599/sasana.v6i1.173

Simajuntak, P.N.H., Hukum Perdata Indonesia, Jakarta: KENCANA, 2015.

Saleh, K.Wantjik, Hukum Perkawinan Indonesia, Jakarta:Ghalia Indonesia, 1980.

Kompilasi Hukum Islam

Alinapia, "Akibat Hukum Pembatalan Perkawinan Karena Status Wali Nikab Yang Tidak Sab Menurut Undang-Undang Nomor 1 Tabun 1974", Jurnal Justitia, Vol 1, No 4, Desember 2014 , hlm 379.

Faisal, "Pembatalan Perkawinan dan Pencegahannya", Jurnal Hukum Islam dan Perundangundangan, Vol 4 No 1 Tahun 2017, hlm 10-15

Ja'far, Kumedi. Hukum Keluarga Islam Di Indonesia, Sukabumi:Arjasa Pratama, 2020

Results of an Interview with Mr. Muhyar, a Judge of the Bekasi Religious Court, on June 12,2020

Zein, Henni. "Pembatalan Perkawinan Karena Kawin Paksa”, Tesis, 2013

Muhlis, Achmad, HUKUM KAWIN PAKS A DIBAW AH UMUR: Tinjanan Hukum Positif Dan Islam, Surabaya: CV. Jakad, 2019. 